\title{
THE APOSTOLIC CONSTITUTION ANGLICANORUM COETIBUS: AN ANGLICAN JURIDICAL PERSPECTIVE
}

\author{
Norman Doe ${ }^{1}$
}

The Apostolic Constitution, Anglicanorum coetibus, and its Complementary Norms, approved by Pope Benedict XVI on 4 November 2009, provide for the foundation of personal ordinariates for Anglicans seeking full communion with the Latin Church. From an Anglican perspective, this development raises a host of fascinating practical and juridical questions. This short paper deals with three issues: (1) responses to the Apostolic Constitution, especially Anglican responses; (2) the Apostolic Constitution itself, with particular reference to Anglican canonical categories within it (such as that of the Anglican Communion and its patrimony); and (3) some relevant legal provisions of or applicable to Anglican Churches which may either obstruct progress or facilitate progress around the initiative. The paper ends with brief conclusions.

\section{Responses to the Apostolic Constitution}

The Apostolic Constitution has aroused widespread interest within global Anglicanism. ${ }^{2}$ Prior to its announcement, the Archbishop of Canterbury and the Roman Catholic Archbishop of Westminster made a joint statement: the Constitution ended uncertainty for groups seeking "new ways of embracing unity with the Catholic Church"; it was now for those who had requested provision to respond; the Constitution itself is further recognition of the substantial overlap in faith, doctrine and spirituality between the Catholic Church and the Anglican tradition; and the Constitution "is one consequence of ecumenical dialogue between the Catholic Church and the Anglican Communion"; however, the two Archbishops stressed that on-going official dialogue provides "the basis for our continuing cooperation". 3 Queen Elizabeth II, supreme governor of the Church of England, also asked her Lord Chamberlain to speak privately with the Archbishop of Westminster on the matter. ${ }^{4}$

Whilst generally the governing bodies of Anglican churches have not (as yet) pronounced formally on the subject, several leading Anglicans worldwide have responded publicly to the Constitution. The Constitution itself had been stimulated by approaches to Rome from individuals and groups (such the Traditional Anglican Communion) opposed to developments within Anglicanism over the ordination of

\footnotetext{
${ }^{1}$ Norman Doe, Professor of Law and Director of the Centre for Law and Religion, the Law School, Cardiff University, is author of several books, including Canon Law in the Anglican Communion (Oxford, 1998); he has served as a canon law consultant to the Primates of the Anglican Communion and the Lambeth Conference, and on the Lambeth Commission 2004. This paper was given by invitation at a seminar of Consociatio internationalis iuris canonici promovendo, Rome, 9 April 2010. ${ }^{2}$ In England, for example, there is to be a conference on the subject at Pusey House, Oxford, on 24 April 2010 entitled “Anglicanorum Coetibus: An Exploration of Anglican Patrimony".

3 Joint Statement, 20 Oct. 2009. The secular press portrayed the Apostolic Constitution variously as a "humiliation" of the Archbishop of Canterbury, that it is designed to "poach Anglican manpower to fill the Pope's depleted ranks", and that it is "damaging to Anglican morale": see, C. Longley, "The Church of England is close to the heart of what it means to be English", The Tablet, 19 Dec. $2009,7$. ${ }^{4}$ M. Greaves and E. Pentin, The Catholic Herald, 5 February 2010.
} 
women as priests, ordination and homosexual practice, and liturgical revision. ${ }^{5}$ Not surprisingly, the responses cover a wide spectrum of positive and negative views.

One concern for some has been whether or not the process leading to the Apostolic Constitution was an exercise in ecumenism; some see it as an exercise in unilateralism. ${ }^{6}$ Certainly, the Apostolic Constitution itself seems to present the scheme within it as a quasi-ecumenical initiative, with its focus on the "scandal" of division amongst baptized people and "the Churches and Christian Communities separated" from the Catholic Church. ${ }^{7}$ However, the waters became perhaps a little muddied when Cardinal Kasper felt it necessary to offer reassurance to Anglicans that the Constitution was not a substitute for ecumenical dialogue between Anglicans and Rome. ${ }^{8}$ Indeed, at a meeting on 21 November 2009 the Pope and the Archbishop of Canterbury reaffirmed their desire to strengthen ecumenical relations between Anglicans and Catholics. As a result, a committee met on 23 November to prepare the next (third) phase of the work of the Anglican-Roman Catholic International Commission (ARCIC), to deal with fundamental questions about the Church as communion and ethical teaching. ${ }^{9}$ Nevertheless, others see the Constitution as a distraction from "the real goal of ecumenical conversation between the largest (Roman Catholic) and third largest (Anglican) Christian communion in the world."10 According to some, the Apostolic Constitution is inconsistent with the spirit of Unitatis redintegratio, and, rather, has "a triumphalistic accent". 11

Many responses consider that a mass exodus of Anglicans is unlikely. Several leaders, such as Archbishop Hiltz, primate of the Anglican Church of Canada, "do not foresee a groundswell of response" to the Constitution, but rather "even among those who have separated themselves from the Anglican Church of Canada, there is an abiding desire to remain in communion with the Archbishop of Canterbury, and to maintain a place within the family of churches" that is the Anglican Communion." One opinion is that ordinariates will be more attractive to those who left Anglicanism

\footnotetext{
${ }^{5}$ The Traditional Anglican Communion (TAC) was founded in 1991 and it is understood that in 2007 its bishops made a formal request for "full, corporate and sacramental union" with Rome. TAC, which claims to have about half a million members in 44 countries, is not a part of the Anglican Communion but is under the leadership of Archbishop John Hepworth of Australia.

${ }^{6}$ See eg Bishop Christopher Epting, The Episcopal Church USA, who observed that the constitution "may be understood as 'pastoral' but is not necessarily very ecumenical.... This appears to be a unilateral action on the part of the Congregation for the Doctrine of the Faith which flies in the face of the slow, but steady progress made in the real ecumenical dialogue of over forty years": Episcopal Life Online, 16 Nov. 2009: http://www.episcopalchurch.org/79901_116893_ENG_HTM.htm

${ }^{7}$ Apostolic Constitution, Anglicanorum coetibus (hereafter ACAC), Introduction.

${ }^{8}$ Made in L'Osservatore Romano, 15 November 2009; see also Bishop C. Hill, Bishop of Guildford in the Church of England, "What is the personal ordinariate: canonical and liturgical observations": http://www.cofe.anglican.org/news/prguildapcon.html; see also K. Kasper, "Still a place for optimism", The Tablet, 13 Feb. 2010, 8, in which Cardinal Kasper expresses his hopes for the ecumenical enterprise (in edited extracts from his opening address to "Harvesting the fruits" symposium held in Rome earlier that month).

${ }^{9}$ See also the report of the International Anglican-Roman Catholic Commission on Unity and Mission (IARCCUM), Growing Together in Mission and Unity (SPCK, 2007), which incidentally makes no mention of the role of canon law in dialogue.

${ }^{10}$ Bishop Christopher Epting, Episcopal Life Online, 16 Nov. 2009.

${ }^{11}$ Bishop Pierre Whalon: Episcopal Life Online, 30 Nov. 2009.

12 Quoted in L.A. Williams, "Vatican publishes plan for full communion with disaffected Anglicans", Anglican Journal, 12 Nov. 2009.
} 
in the 1970s and 1980s (over the ordination of women). ${ }^{13}$ Some consider that many Anglican clergy already using the Roman Missal (or elements of it) are unlikely either to abandon these practices or join an ordinariate. ${ }^{14}$ Another view identifies as a possible deterrent the pressures on Anglicans seeking reception in the Latin Church in terms of the changes in the doctrinal posture required of them. ${ }^{15}$

Some Anglicans are sceptical about the "Anglican patrimony" which members of ordinariates will be able to retain. For example, clergy of the Church of England would leave behind their pastoral and evangelistic ministry, currently exercised for the whole community beyond congregations (including eucharistic ministry to the divorced) - this is a fundamental of the established position of the Church of England; both clergy and laity would leave behind a unique architectural and cultural heritage (and the resonances these carry); clergy in service would lose further contributions to their pension fund; and the laity would leave behind the right to exercise the power of governance in the church. ${ }^{16}$ Others criticise the provision in the Constitution for corporate reception of groups into the Latin Church, arguing that such decisions should be made on an individual not a collective basis. ${ }^{17}$ Generally, however, Anglican leaders commend with their blessing "any Anglican who in good conscience wishes to become a Roman Catholic" in the same way that they welcome "any Roman Catholic who in good conscience wishes to enter into full communion... with the See of Canterbury, and therefore with the Anglican Communion."18

On the other hand, those who sought the provision welcome it greatly. It opens "a new way into unity with the See of Peter". ${ }^{19}$ The Pope has displayed "huge understanding and compassion for traditional Anglicans" in an act of "incredible generosity and vision" helping to redeem recent disappointment and despair. ${ }^{20}$ Indeed, a Special General Meeting of Members of Forward in Faith Australia, held on 13 February 2010 in Melbourne, directed its National Council to foster by every means the establishment of an ordinariate in Australia; moreover, it affirmed its commitment to provide care and support for those who feel unable to be received into the ordinariate; it welcomed the appointment of Bishop Peter Elliott as delegate of the

\footnotetext{
${ }^{13}$ Bishop Dennis Drainville, Diocese of Quebec, co-chair of the Anglican-Roman Catholic Bishops' Dialogue - however, it might affect larger numbers in England "because they are just going through their crisis about women in Episcopal orders": Williams, op cit. See also V. Combe, "Living apart together", The Tablet, 13 Feb. 2010, 6: this carries the opinion that whilst evangelicals and AngloCatholics are both against women bishops, the former will not join an ordinariate, but the latter might. ${ }^{14} \mathrm{~S}$. Trott, , "You don't know what you've got till it's gone", Church Times, 11 Dec. 2009.

${ }^{15}$ Bishop Drainville: "So if Anglicans are going to truly be part of this then there are a number of things they are going to have to accept, the Catholic Church's dogma on trans-substantiation is still there, the Petrine doctrine of the supremacy of the Pope and infallibility are central... Whoever is going to make this move is going to have to move accepting all of that": Williams, op cit.

${ }^{16}$ S. Trott, "You don't know what you've got till it's gone", Church Times, 11 Dec. 2009.

${ }^{17}$ Bishop Epting: "the Vatican may rest assured that there will be no "Roman Catholic Ordinariates" within the Anglican Communion for former, disaffected Roman Catholic converts. We will continue to welcome individuals, from the Roman Catholic Church or any other Christian communion, who desire to be in full communion": Episcopal Life Online, 16 Nov. 2009.

${ }^{18}$ Ibid; the Archbishop of York is reported to have said on BBC Radio Ulster's Sunday Sequence programme that people joining an ordinariate would not be "proper Catholics": see V. Combe, "Living apart together", The Tablet, 13 February 2010, 6.

${ }^{19}$ B. Bishop of Ebbsfleet quoted in B. Bowder, "Anglo-Catholics gather to pray over Pope's offer", Church Times, 26 Feb. 2010.

${ }^{20}$ A. Reader-Moore, “Anglo-Catholics do have a real patrimony”, The Catholic Herald, 22 Jan. 2010.
} 
Australian Catholic Bishops' Conference in the project to establish such an ordinariate; the meeting also established the Friends of the Australian Ordinariate. ${ }^{21}$

In turn, there are press reports of about 100 traditionalist Anglican parishes across the United States converting to the Catholic Church in response to the Constitution, and that the Anglican Church in America (ACA) - a member of the Traditional Anglican Communion - has decided formally to make a request to enter the Catholic Church as a block, bringing an estimated 5,200 converts along with their own bishops, clergy, buildings and even a cathedral. ${ }^{22}$ Forward in Faith in the United Kingdom is also considering a similar approach and has set up its own Friends of the Ordinariate. ${ }^{23}$ In preparation for this, some say that the Episcopal Conference of England and Wales has established a commission to explore for example the possibility of church-sharing and taking out 100-year leases of some Anglican places of worship. The timing of the forthcoming visit of Pope Benedict to the United Kingdom, to attend the beatification of Cardinal John Henry Newman, might prove significant for recruitment. ${ }^{24}$ There are also reports of more than forty Anglican parishes in Canada seeking an ordinariate. ${ }^{25}$

\section{The Terms of the Apostolic Constitution: Anglican Understandings}

The reception of Anglican groups into the Latin Church, and the retention of their liturgical traditions, is not new. The "Anglican Use Parishes" have of course existed since the Pastoral Provision of Pope John Paul II in 1980; these are parishes of the Latin Church which retain elements of Anglican liturgy in their worship whilst remaining fully Catholic. ${ }^{26}$ Similarly, the erection of ordinariates under Anglicanorum Coetibus is not entirely new. Though the category "ordinariate" is not explicitly found in the Code of Canon Law 1983, Anglicans understand that the model for it lies in military ordinariates; Fr. Ghirlanda recognises this in his commentary on the Apostolic Constitution. ${ }^{27}$ In turn, as with a military ordinariate, ${ }^{28}$ an ordinariate

\footnotetext{
${ }^{21}$ See eg G. Conger, “Australians are first to take up Pope's offer”, The Church of England Newspaper, 19 Feb. 2010, 7: this provides the basics of the decisions. See also Forward in Faith Australia, 15 Feb. 2010: http://www.forwardinfaith.com/artman/publish/article_501.shtml

${ }^{22}$ S. Caldwell, "US Anglicans to convert to Rome en masse", The Catholic Herald, 12 March 2010: The decision was taken by the House of Bishops of the ACA during a meeting in Orlando, Florida, which was attended by the primate of the Traditional Anglican Communion, Archbishop John Hepworth. The bishops said in a brief statement on their website afterwards that they had agreed formally to "request the implementation of the provisions of the Apostolic Constitution Anglicanorum coetibus in the United States of America by the Congregation for the Doctrine of the Faith". The ACA House of Bishops also proposes to seek guidance from Anglican Use Parishes.

${ }^{23}$ Ibid: the report suggests this might involve in the region of 200 Anglican congregations, which would amount to thousands of converts: Caldwell. See also T. Cohen, "Delay in Vatican vote", The Church of England Newspaper, 26 Feb. 2010: a decision from Forward in Faith (UK) is likely following the July 2010 meeting of the General Synod (which will consider women bishops).

${ }^{24}$ S. Caldwell, "US Anglicans to convert to Rome en masse", The Catholic Herald, 12 March 2010.

${ }^{25}$ The leaders of the Anglican Catholic Church of Canada - a member of the breakaway Traditional Anglican Communion (TAC) - have sent a petition to the Vatican requesting full communion with Rome through the implementation of Anglicanorum coetibus: The Catholic Herald, 19 March 2010. ${ }^{26}$ For example, in the USA: the parish of Our Lady of the Atonement Catholic Church, Archdiocese of San Antonio, Texas (this has no affiliation to the so-called "Continuing Anglican Movement"; its Order of Mass, drawing on the 1928 and 1979 Book of Common Prayer of the Episcopal Church USA, consists of Rite I (traditional English) and Rite II (contemporary English); Our Lady of Walsingham, Archdiocese of Galveston-Houston, and the parish of St Thomas More, Fort Worth, Texas.

${ }^{27}$ Fr. G. Ghirlanda, "The significance of the Apostolic Constitution Anglicanorum Coetibus", as published on the official website of the Vatican (9-11-2009) and in Osservatore Romano (10-11-2009);
} 
for Anglicans is equivalent to a diocese and possesses public juridical personality; ${ }^{29}$ the power of its ordinary (appointed by the Roman Pontiff and to whom pastoral care is entrusted) is vicarious and personal. ${ }^{30}$ To be erected by the Congregation for the Doctrine of the Faith, each ordinariate is not territorial, though an ordinariate will be erected "within a territory", and its erection may lead to the creation of personal parishes. ${ }^{31}$ The ordinary enjoys 'legitimate autonomy' from the local bishop but at the same time exercises authority 'together with the Diocesan Bishop', and pastors of the ordinariate are to minister in mutual assistance with local pastors. ${ }^{32}$ Anglicans are familiar with the concept of non-territorial structures for ministry and pastoral care: ministry to the armed forces, with episcopal oversight, is an example of this. ${ }^{33}$

Secondly, some Anglicans seem to think that members of an ordinariate will remain "Anglican" in terms of canonical status. ${ }^{34}$ This is clearly not the case from the Catholic perspective. Whilst the Apostolic Constitution itself speaks of "Personal Ordinariates for Anglicans", for "those faithful Anglicans who desire to enter into the full communion of the Catholic Church in a corporate manner", an ordinariate will be composed of members "originally belonging to the Anglican Communion and now in full communion with the Catholic Church", 35 it explicitly speaks of clerical members

see www.zenit.org; Fr. Ghirlanda also concedes that "Personal Ordinariates for Anglicans" are not envisioned in the Code of Canon Law.

${ }^{28}$ The Canon Law: Letter and Spirit, Canon Law Society of Great Britain and Ireland (Dublin, 1995), para. 1112: 'The armed forces in any country constitute a community with very special needs and problems. The "special laws" mentioned in the canon are contained in ap con Spirituali militum curae of 21 April 1986 and in the statutes approved by the Holy See for each country or region'; see also para. 1113: 'Where a military ordinariate is created, it is equivalent to a diocese (see Cann. 368-369). The powers of the military Ordinary are proper, and he is equivalent to a diocesan Bishop wherever this is mentioned in the Code. In some countries, for practical reasons, the office is combined with that of a diocesan Bishop. Whether this be so or not, the military Ordinary belongs to the Bishops' Conference. The extent of the responsibilities of the Ordinary and of the chaplains is specified in the norms for each country. Jurisdiction is personal, and so it applies outside national boundaries to those who pertain to the ordinariate. The jurisdiction of the military Ordinary and of the chaplains is cumulative with that of the diocesan Bishop and clergy... A full-time military chaplain is, in effect, the parish priest of a personal parish (see Can. 518), belonging to the military ordinariate and possessing all the rights and obligations of a parish priest'.

${ }^{29}$ ACAC, I.3: "juridically comparable to a diocese", each ordinariate possesses public juridical personality by the law itself; see also XIII: "The Decree establishing an Ordinariate will determine the location of the See and, if appropriate, the principal church".

${ }^{30}$ ACAC, V: bishops have ordinary, proper and immediate power (CIC, c. 381.1); they are not "vicars" (representatives) of the pontiff but vicars and legates of Christ (Lumen gentium, 27); a vicar general or episcopal vicar exercises ordinary jurisdiction by delegation (c. 131.1 and 2); as do auxiliary or coadjutor bishops; in an ordinariate, ordinary power is exercised vicariously, not being proper to the office.

${ }^{31}$ The ordinariates for Anglicans are personal structures in so far as the jurisdiction of the ordinary and of parish priests "is not geographically defined within the territory of an Episcopal Conference like a particular territorial Church, but is exercised 'over all who belong to the Ordinariate"': Ghirlanda (citing ACAC. V); see also ACAC I. 2; for personal parishes see CIC, c. 518.

${ }^{32}$ Ghirlanda: the personal prelatures model (c. 294-97) was not followed; under c. 294 personal prelatures are composed of secular priests and deacons and (under c. 296) law people may simply dedicate themselves to the apostolic works of personal prelatures by agreement.

33 See N. Doe, Canon Law in the Anglican Communion (Oxford, 1998) 123-4.

34 This observation is based on personal conversations with many. See also Anglican Communion in America (ACA) website for Frequently Asked Questions, ACA House of Bishops Endorsement of Apostolic Constitution, 8: "united, but not absorbed' will be the guiding principle of our relationship". ${ }^{35}$ ACAC, Introduction and I.1 and I.4. 
as those "who ministered as Anglican deacons, priests, or bishops", 36 and the Complementary Norms speak of "former Anglicans ministers". 37 Fr. Ghirlanda too considers that an ordinariate is open (amongst others) to "those coming from Anglicanism" or those who had "previously adhered to Anglicanism". ${ }^{38}$ There is no category, in the Apostolic Constitution, of Anglo-Catholic or Anglican Catholic or Catholic Anglican. Indeed, the Constitution provides for their full integration into the Latin Church: certainly they are not members of the Latin Church diocese in which they are domiciled, ${ }^{39}$ but they will be registered with the ordinariate. ${ }^{40}$ The marks of their integration in the Latin canonical order are clear: they must accept the Catholic Catechism; ${ }^{41}$ they must be confirmed, and Anglican ministers must be ordained to exercise the functions of priests. ${ }^{42}$ The ordinariate will be within the territory of an Episcopal Conference. ${ }^{43}$ Its ordinary exercises authority together with the diocesan bishop; ${ }^{44}$ and will be a member of an Episcopal Conference. ${ }^{45}$ Clerical formation is integrated, ${ }^{46}$ and any "Anglican clergy who are in irregular marriage situations may not be accepted" for admission to holy orders in the ordinariate, ${ }^{47}$ no married men may be admitted to the episcopate. ${ }^{48}$ Priests will be incardinated into the ordinariate. $^{49}$ There must be mutual cooperation between ordinariate clergy and diocesan clergy ${ }^{50}$ and ordinariate clergy are eligible for election to the Presbyteral Council and the Pastoral Council of a diocese. ${ }^{51}$ Personal parishes may be erected within an ordinariate after consultation with diocesan bishop and with the consent of the Holy See $;^{52}$ where there is no personal parish, the ordinary may after consultation with the local diocesan bishop make provision for quasi-parishes. ${ }^{53}$ Provision also

\footnotetext{
${ }^{36}$ ACAC, VI.1.

${ }^{37} \mathrm{CN}$, Art. 4.2.

${ }^{38}$ Ghirlanda, "The significance...": namely, those "who have repeatedly petitioned the Holy See to be received into full Catholic Communion"; this suggests that the scheme is for currently practising Anglicans who are still members of their own respective churches. The erection of an ordinariate is "[t]he juridical means by which the Holy Father has decided to receive these Anglicans into full Catholic communion".

${ }^{39}$ Ibid: this may be compared with the scheme in Pastoral Provision adopted by the Congregation for the Doctrine of the Faith and approved by John Paul II 20 June 1980, under which the faithful coming from Anglicanism were members of the diocese in which they were domiciled receiving special care from the diocesan bishop.

${ }^{40}$ Ibid (there is something here of Anglican polity in which parochial electoral rolls or other registers are used); ordinariates are designed to enable reception "corporately" "for groups composed of people in various states of life" (lay, clerical and religious). The ordinary "enjoys legitimate autonomy with respect to the jurisdiction of the Diocesan Bishop in which the faithful of the Ordinariate have their domicle and is, therefore, better able to ensure that those faithful are not simply assimilated into the local Dioceses in a way which would lead to the loss of the richness of their Anglican tradition" but the ordinary must ensure the ordinariate "does not evolve into an isolated community".

${ }^{41}$ ACAC, I.5.

${ }^{4} \mathrm{CN}$, Art. 5: they must make their Profession of Faith and have received the Sacraments of Initiation (under CIC, c. 845), ie baptism and confirmation.

${ }^{43}$ ACAC, I.2.

${ }^{44}$ ACAC, V, CN, Art. 5.2.

${ }^{45} \mathrm{CN}$, Art. 2: and the ordinary will be obliged to follow its directives unless incompatible with the
} Apostolic Constitution.

46 ACAC VI.5; CN Art. 10.2.

${ }^{47} \mathrm{CN}$, Art. 6.2.

${ }^{48} \mathrm{CN}$, Art. 11.1.

${ }^{49} \mathrm{CN}$, Art. 4.2.

${ }^{50}$ ACAC, VIII.2; CN, Art. 14.2.

$51 \mathrm{CN}$, Art. 8.1 and 8.2.

${ }^{52}$ ACAC, VIII.1; see also CN, Art. 14.

${ }^{53} \mathrm{CN}$, Art. 14.3; see CIC, can. 516.1. 
exists for a tribunal. ${ }^{54}$ As Fr. Ghirlanda points out, these norms are designed for the integration (if not assimilation) of the former Anglicans into communion with the Latin Church. ${ }^{55}$ Similar integration would follow reception into Anglican churches. ${ }^{56}$

Equally, however, the Apostolic Constitution provides for the continuation of elements of Anglican identity. In terms of liturgy, each ordinatiate has the faculty to celebrate the Eucharist and other sacraments, the Liturgy of the Hours and other liturgical celebrations according to the liturgical books proper to the Anglican tradition and approved by the Holy See, without however, excluding liturgical celebrations according to the Roman Rite. ${ }^{57}$ In terms of ministry, in each ordinariate a "married former Anglican Bishop is eligible to be appointed Ordinary" (once ordained a priest in the Catholic Church) $;{ }^{58}$ to provide for "formation in Anglican patrimony", the ordinary may establish seminary programmes or a house of formation; ${ }^{59}$ those who ministered as Anglican deacons, priests and bishops may be admitted to holy orders; ${ }^{60}$ the ordinary may petition the Roman Pontiff (on a case by case basis) to admit married men to the priesthood although the general norm is to admit only celibate men. ${ }^{61}$ In terms of institutional structure, the Apostolic Constitution provides for the erection of personal parishes after consultation with the diocesan bishop and with the consent of the Holy See ${ }^{62}$ it allows for the reception of religious communities (to be placed under the jurisdiction of the ordinary by mutual consent); ${ }^{63}$ and it provides "respect for the synodal tradition of Anglicanism". ${ }^{64}$ However, some of these provisions have been heavily criticised: "Any former Anglican who has been ordained will not only have to be re-ordained as a priest in the Roman Catholic Church, not only re-ordained as a transitional deacon, but even re-

\footnotetext{
${ }^{54}$ Its competent tribunal is that for the diocese if the ordinariate has not constituted its own (AC XII).

${ }^{55}$ Ghirlanda, "The significance...": ordinariates respond to two needs: the need "to maintain the liturgical, spiritual and pastoral traditions of the Anglican Communion within the Catholic Church, as a precious gift nourishing the faith of the members of the Ordinariate and as a treasure to be shared" (AC III); and the need to integrate fully into the life of the Catholic Church groups of faithful, or individuals, coming from Anglicanism; the enrichment is mutual: the faithful coming from Anglicanism receive the richness of the spiritual, liturgical and pastoral tradition of the Latin Roman Church "in order to integrate it into their own tradition, which integration will in itself enrich the Latin Roman Church. On the other hand, exactly this Anglican tradition - which will be received in its authenticity in the Latin Roman Church - has constituted within Anglicanism precisely one of those gifts of the Church of Christ, which has moved these faithful towards Catholic unity"; to protect and nourish the spiritual, liturgical and pastoral tradition developed within Anglicanism "and recognised as authentic by the Catholic Church".

${ }^{56}$ See N. Doe, Canon Law in the Anglican Communion (Oxford, 1998) 162: "received members" are those who, after appropriate instruction, and a mature public declaration of their faith, are received by a bishop into the institutional church in question; see also Principle 99 of the Principles of Canon Law Common to the Churches of the Anglican Communion (Anglican Communion Office, 2008).

${ }^{57}$ ACAC, III.

${ }^{58} \mathrm{CN}$, Art. 11.1; former Anglican bishops may also be called upon to assist the ordinary in administration of the ordinariate (11.2); invited to participate in meetings o the Episcopal Conference (with the status of a "retired bishop": 11.3); and may request permission from the Holy See "to use the ensignia of the episcopal office": 11.4.

59 ACAC, VI.5; CN, 10.2 and 4.

60 ACAC VI.1; they may be ordained priests according to the norms of the Encyclical Letter of Paul VI Sacerdotalis coelibatus, n. 42 and the Declaration In June.

${ }^{61}$ ACAC, VI.2 (ie as a derogration of CIC, c. 227.1.

${ }^{62}$ ACAC, AC VIII.1; this is possible under CIC, c. 518.

${ }^{63}$ ACAC, VII: the ordinary may erect new institutes of consecrated life and societies of apostolic life.

${ }^{64}$ Ghirlanda, "The significance..."; ACAC, X: governing council of six priests (to assist the ordinary); finance council; and pastoral council which includes laity (for consultation); see also CN, Art. 12.
} 
confirmed as an adult member of the Body of Christ! Any one who does make this move is not an Anglican, nor an Anglo-Catholic, but a Roman Catholic convert". ${ }^{65}$ Others have rightly pointed out that there is nothing particularly new in these provisions. ${ }^{66}$ In any event, currently, no church in the Anglican Communion has analogous provisions applicable to the reception of groups into those churches; indeed, Anglican churches also have criteria for recognition of valid holy orders. ${ }^{67}$

In its portrayal of Anglicanism, the Apostolic Constitution uses several categories unfamiliar to Anglican canon law - that is, categories not found in the legal systems of churches in the Anglican Communion, or in the principles of canon law common to those churches. ${ }^{68}$ Unlike the notion in the Apostolic Constitution that "belonging to the Anglican Communion" is enjoyed by individuals, ${ }^{69}$ Anglicans see the Anglican Communion as composed not of individuals but of institutional churches. ${ }^{70}$ The "Anglican tradition", and "Anglican patrimony", 71 are not canonical categories in Anglicanism, though "tradition" and "catholic tradition" are. ${ }^{72}$ Similarly, the laws of Anglican churches speak of "forms of service" or "service books", rather than "liturgical books"; 73 and the Liturgy of the Hours is not a category in the laws of churches. ${ }^{74}$ However, these categories in the Apostolic Constitution are outnumbered by those which are familiar to Anglican canon law; these include: the notion of "the Anglican Communion within the Catholic Church"; 75 the need for structures in the visible life of the church $;^{76}$ the idea that norms must have a theological foundation; $;^{77}$ the concept of an ordinary $;{ }^{78}$ the principle that there is no right to ordination; ${ }^{79}$ the duty to seek ecumenical dialogue $;{ }^{80}$ the remuneration of

\footnotetext{
65 Bishop Christopher Epting, Episcopal Life Online, 16 Nov. 2009.

66 The provisions are of course based on the position of Rome on Anglican orders, and many appreciate them in that light: Bishop Christopher Hill, op cit.

${ }^{67}$ N. Doe, Canon Law in the Anglican Communion (Oxford, 1998) 364ff. See also PCLCCAC, Principle 94.

${ }^{68}$ Principles of Canon Law Common to the Churches of the Anglican Communion (Anglican
} Communion Office, 2008), hereafter PCLCCAC.

${ }^{69}$ ACAC, I.4, and IX.

${ }^{70}$ PCLCCAC, Principle 10.1: "The Anglican Communion is a fellowship of churches within the One, Holy, Catholic and Apostolic Church, characterised by their historic relationship of communion with the See of Canterbury"; the Communion consists of "duly constituted national, regional, provincial churches and dioceses". See also the Anglican Communion Covenant, 4.1.1.

${ }^{71}$ ACAC, III (Anglican tradition); VI.5 (Anglican patrimony); Anglicans have been much exercised by the latter category: see, typically, S. Trott, 'You don't know what you've got till it's gone', Church Times, 11 Dec. 2009.

${ }^{72}$ PCLCCAC, Principle 8.4 (interpretation of law may in cases of doubt have recourse to, inter alia, "practice and tradition"; Principle 9.2 (catholic tradition)

${ }^{73}$ PCLCCAC, Principle 54.5 and 8 and 55 (however, see 55.8 for "liturgical text").

${ }^{74}$ Morning Prayer and Evening Prayer are the traditional canonical categories: see N. Doe, Canon Law in the Anglican Communion (Oxford, 1998) 234.

${ }^{75}$ ACAC, III; see above n. 70 for PCLCCAC, Principle 10.1.

${ }^{76}$ ACAC, Introduction; PCLCCAC, Principle 1.2: "A church needs within it laws to order, and so facilitate, its public life and to regulate its own affairs for the common good".

77 ACAC, Introduction: "In the light of these ecclesiological principles, the Apostolic Constitution provides the general normative structure for regulating the institution and life of Personal Ordinariates"; PCLCCAC, Principle, 2.3: "Law has a historical and a theological foundation, rationale and end"; 2.4: "Law is intended to express publicly the theological self-understanding and practical policies of a church".

${ }^{78}$ ACAC, V; PCLCCAC, Principle 38.4: “An assistant bishop is subject to the ordinary jurisdiction of the diocesan bishop".

${ }^{79}$ PCLCCAC, Principle 32.3. 
clergy $;{ }^{81}$ the permission for clergy to engage in a secular profession $;{ }^{82}$ the notion of membership of an ecclesial entity; ${ }^{83}$ and many others. ${ }^{84}$

All this suggests that it is very surprising not to see in the Apostolic Constitution any reference at all to the "canonical tradition" of Anglicanism, ${ }^{85}$ alongside, that is, references to its "liturgical, spiritual and pastoral traditions". ${ }^{86}$ Fr. Ghirlanda recognises, for example, that "out of respect for the synodal tradition of Anglicanism", the ordinary is to be assisted by a Pastoral Council ${ }^{87}$ the synodal tradition is of course part of the canonical tradition of Anglicanism. ${ }^{88}$ The omission is especially surprising given the work of the Colloquium of Anglican and Roman Catholic Canon Lawyers. Set up in 1999, at a meeting which included an audience with Pope John Paul II (and a later one included an audience with Pope Benedict XVI), the Colloquium has over ten years compared the juridical systems of the Latin Church and churches in the Anglican Communion. Its role is to identify similarities and differences, in a very detailed manner, and articulate shared principles, with a view to exploring how these contribute to greater visible communion between the two traditions. The Colloquium has examined church property, ${ }^{89}$ clerical discipline, ${ }^{90}$ rites of initiation and authority, ${ }^{91}$ holy orders, primacy, and clerical formation, ${ }^{92}$ and marriage. $^{93}$ These encounters have always been marked by academic rigour, candid exchanges of views, respectful listening, fellowship and shared worship, as well as a deep respect for the respective doctrinal positions of the parties. ${ }^{94}$

Both the Anglican Communion and the Catholic Church are governed by complex systems of law, but, unlike Catholics, Anglicans have no global canon law. In Anglicanism each of the forty-four churches in the Anglican Communion is

\footnotetext{
${ }^{80}$ ACAC, Introduction; PCLCCAC, Principle 93.1: "The church universal is indivisible and it is the will of God that separated churches should share a more visible communion than exists one with another".

${ }^{81} \mathrm{CN}$, Art. 7.1 and 2; PCLCCAC, Principle 91.1: "A church should provide for the financial maintenance of ministry, both lay and ordained"; 91.2: "Ministers in full-time ministry have a legitimate expectation to a stipend or other remuneration payable by virtue of the office or other position held by them".

${ }^{82} \mathrm{CN}$, Art. 7.3; PCLCCAC, Principle, 41.4: "Clergy must not engage in any secular employment or other occupation outside their ministry without consultation with, or as the case may be permission from, the diocesan bishop or other relevant church authority".

${ }^{83} \mathrm{CN}$, Art. 8.1; PCLCCAC, Principle 27.

${ }^{84} \mathrm{Such}$ as the notion of norms, rights and duties: PCLCCAC, Principle 4.

${ }^{85}$ See for example, PCLCCAC, Principle 3: "Historical sources recognised as such in the canonical tradition, including custom, have such status within a church as may be prescribed by law".

${ }^{86}$ ACAC, III: though the spiritual and pastoral traditions are nowhere defined.

${ }^{87}$ Ghirlanda, "The significance...".

${ }^{88}$ PCLCCAC, Principle 18.1: "Representative government is fundamental to church polity, and in matter which touch all, all should have a voice".

${ }^{89}$ See generally J. Fox (ed), Render Unto Caesar: Church Property in Roman Catholic and Anglican Canon Law (Rome, 2000).

${ }^{90}$ M. Hill (ed), Clergy Discipline in Anglican and Roman Catholic Canon Law (Cardiff and Rome, 2001).

${ }^{91}$ J. Conn, N. Doe and J. Fox (eds), Initiation, Membership and Authority in Anglican and Roman Catholic Canon Law (Rome, 2005).

92 N. Doe (ed), The Formation and Ordination of Clergy in Anglican and Roman Catholic Canon Law (Cardiff, 2009).

${ }_{93}$ N. Doe (ed), Marriage in Anglican and Roman Catholic Canon Law (Cardiff, 2009).

94 "A Decade of Ecumenical Dialogue in Canon Law", Report of the Proceedings of the Colloquium of Anglican and Roman Catholic Canon Lawyers 1999-2009 (2009) 11 Ecclesiastical Law Journal, 284.
} 
autonomous, with its own legal system; however, The Principles of Canon Law Common to the Churches of the Anglican Communion induced from the similarities between their legal systems (and launched at the Lambeth Conference in 2008), represents a significant innovation in the Anglican landscape. ${ }^{95}$ But The Principles do not have the juridical authority that is provided for the Catholic Church by its two Codes (Latin and Eastern). Indeed, the ecclesiologies of Catholicism and Anglicanism emphasise either a universal papal authority and espiscopal collegiality or provincial and national autonomy. Nevertheless, Anglicans and Catholics agree that scripture and tradition are fundamental sources for canon law. In Anglicanism, making law involves the laity more than occurs among Catholics, who stress the clerical nature of the power of governance. There is a good deal in common as to the subjects dealt with by the respective laws, not least in governance, ministry, property and the sacraments. Now - on a more general point about Anglican-Catholic dialogue, canon law can be perceived as an obstacle to the advancement of fuller visible communion because of its need for clarity, certainty and stability. This may partly explain why canon law has been the missing link both in ecumenical dialogue and in the Apostolic Constitution. However, given its thoroughly theological nature and its capacity to order and facilitate Christian life and mission, it definitely has its place. On the wider ecumenical canvas, by making clear what is not always perceived as clear, by setting out boundaries and limits, canon law serves not just as a useful source of norms regulating ecumenical relations but can be seen as an instrument of that very same dialogue. Canon law helps Catholics and Anglicans see how they are radically united, where progress is yet to be made, and what is simply a legitimately different expression of something shared. ${ }^{96}$ The work of the Collloquium has been fed into that of the International Anglican-Roman Catholic Commission on Unity and Mission.

\section{The Law of Anglican Churches Relevant to the Development}

Fr. Ghirlanda observes in his commentary that many doctrinal questions have had to be addressed in the process leading to the Apostolic Constitution; he also concedes that such questions will continue to arise during the formation of ordinariates and the incorporation of Anglican groups into them. ${ }^{97}$ What follows is an attempt to identify

\footnotetext{
${ }^{95}$ Principles of Canon Law Common to the Churches of the Anglican Communion (Anglican Communion Office, 2008); this is the work of the Anglican Communion Legal Advisers Network; for background to this work see ibid., 97: N. Doe, "The contribution of common principles of canon law to ecclesial communion in Anglicanism". Under the presidency of Archbishop Carey, in 2001 the Primates' Meeting discussed (for the first time) the contribution (or not) made by the laws of the churches to global communion in Anglicanism. At the request of the Primates, an Anglican Communion Legal Advisers Consultation met at Canterbury in 2002 (a first for such a meeting) and proposed that there are principles of canon law common to the churches of the Communion. The Primates in 2002 recognised that 'the unwritten law common of the Churches of the Communion and expressed as shared principles of canon law may be understood to constitute a fifth "instrument of unity"' (alongside the Archbishop of Canterbury, Lambeth Conference, Anglican Consultative Council and Primates`Meeting). The ACC at Hong Kong then established a Network of Legal Advisers to produce a statement of the principles. In 2003, the Primates urged completion of the work, as did the Lambeth Commission in its Windsor Report (2004). The Network launched its work at the Lambeth Conference in 2008.

96 "A Decade of Ecumenical Dialogue in Canon Law", (2009) 11 EccLJ, 284 at 296.

${ }^{97}$ Ghirlanda, "The significance" etc; he also observes that personal ordinariates for Anglicans "cannot be considered as Particular Ritual Churches since the Anglican liturgical, spiritual and pastoral tradition is a particular reality within the Latin Church"; the creation of a Ritual Church might have created "ecumenical difficulties".
} 
elements of the laws of Anglican churches which are relevant to, and may impact on, these processes. Some provisions of Anglican laws may hinder the process. Others may facilitate it. The following identifies a number of laws relevant to these issues.

\section{Anglican Laws which might frustrate the life of an Ordinariate:}

First, whilst Anglicans are of course free to leave the churches of the Anglican Communion, at the same time the faithful are subject to discipline to the extent and in the manner prescribed by law. ${ }^{98}$ The canonical consequences for an Anglican seeking to become a Catholic through admission to an ordinariate will depend on what status that Anglican has in their own province. ${ }^{99}$ Such people may lose their communicant status voluntarily by failure to receive Holy Communion on prescribed occasions (typically three times a year) in that church (or by receiving it in another church with which the Anglican church in question is not in communion). ${ }^{100}$ Communicant status may also be lost involuntarily by means of excommunication if the view is taken (usually by the bishop) that joining an ordinariate causes public scandal or brings the church into disrepute or that the excommunicate has engaged in schism. ${ }^{101}$ The status of enrolled or registered church members may be lost voluntarily, or involuntarily through removal from a roll or register, such as when a person becomes a member of a church which is not in communion with the Anglican church in question. ${ }^{102}$ Loss of membership may also occur through failure to attend worship, or to contribute to the church financially. ${ }^{103}$ Indeed, theoretically, joining an ordinariate may of itself constitute an offence; in many churches of the Anglican Communion breaking communion with that church may be the subject of disciplinary proceedings, if the view is taken that such conduct constitutes schism. ${ }^{104}$ The same applies to holding

\footnotetext{
${ }^{98}$ PCLCCAC, Principle 25.4 (as to the laity); for the clergy, see Principles 41 and 47.

${ }^{99}$ N. Doe, "Termination of membership in Anglican canon law", in J. Conn, N. Doe and J. Fox (eds), Initiation, Membership and Authority in Anglican and Roman Catholic Canon Law (Rome, 2005) 109: it is sometimes difficult to ascertain whether loss of a particular status terminates membership of the institutional church itself, as for the most part loss of status results simply in exclusion from aspects of church life and the enjoyment of rights belonging to the relevant ecclesial status or class. For example, in churches in which baptism effects membership of the institutional church (as well as the church universal), given the indelibility of baptism, this form of membership would seem incapable of termination: see eg The Episcopal Church USA, Can. I.17(1)(a).

${ }^{100}$ See eg Church in Wales, Const., I.7: "communicant" means "a person who has lawfully received Holy Communion in the Church in Wales or some other Church in communion with it and is entitled to receive Holy Communion in the Church in Wales"; for three occasions see eg West Indies, Const. Art. 6.1 and Can. 26.2; see also PCLCCAC, Principle 27.4.

${ }^{101}$ PCLCCAC, Principle 69.2; for schism, see eg West Indies, Can. 26; see also below n. 104.

${ }^{102}$ PCLCCAC, Principle 27.7: names may be removed from a parish roll or other register in accordance with the law and observing the principles of justice and equity; see eg Australia, Const. XII.74.1, and Wales, Const. IV.5: a name shall be removed from the roll if a person "becomes, without the written permission of the Bishop, a member of any religious body which is not in communion with the Church in Wales". However, some churches give communicant status to members of other non-Anglican churches when these are in good standing in that other church: Doe (2005) at 118-119.

${ }^{103}$ See eg Hong Kong Sheng Kung Hui, Can. 25.7: a registered member of a parish is a Christian who is at least 18 , baptised, confirmed, a regular communicant, and "is making monthly contributions to the parish concerned".

${ }^{104}$ See eg Southern Africa, Can. 37.1(g): "schism, that is to say, acceptance of membership in any religious body not in communion with the Church of this Province"; see also eg West Africa, Const. Art. XXXII.6(d)-(f); the Church of England too provides in Canon A8 Of Schisms, that: "it is the duty of clergy and people to do their utmost not only to avoid occasions of strife but also to seek in penitence and brotherly charity to heal such divisions".
} 
and teaching publicly doctrines and opinions contrary to the doctrine of that church. ${ }^{105}$ It also applies to abandonment of clerical ministry by formal admission into another religious body not in communion with the Anglican church in question. ${ }^{106}$ Some churches enable restoration on the abandonment of ministry. ${ }^{107}$ Of course, it will be a matter for each church to determine whether or not disciplinary action is taken against those seeking to join a Catholic ordinariate - though it would be a sad day for ecumenism if such action were taken. However, in the Anglican Church of Australia, a bishop (who is a member of Forward in Faith which has decided to petition Rome for admission to an ordinariate) has recently been the subject of disciplinary charges in the Special Tribunal for, inter alia, claiming that the Anglican Church of Australia is not "a true church" and for attending worship in the Roman Catholic Church whilst several parishes in the diocese are without clergy. ${ }^{108}$

Secondly, there are difficulties if a group of former Anglicans seeks to continue to use their Anglican parish church for worship in accordance with rites which are part of the Anglican liturgical tradition and which have been approved for use in the ordinariate by the Holy See. ${ }^{109}$ The ownership of an Anglican church building does not usually vest in a congregation but in prescribed ecclesiastical bodies (usually at diocesan or provincial level), and the building must be used in accordance with the rules of the church (including any relevant trusts); ${ }^{10}$ a group entering an ordinariate has no inherent right to take the building with them. ${ }^{111}$ Moreover, generally, an Anglican place of worship (such as a parish church) may be used only for the administration of such rites as are authorised under the law of the church in question. ${ }^{112}$ The laws of Anglican churches carefully prescribe which forms of service are authorised for liturgical use and, needless to say, these do not include liturgical texts revised and approved by the Holy See. ${ }^{113}$ The approval of liturgical texts belongs to the central legislative assembly of a church (its general synod, provincial council, or other central

${ }^{105}$ See N. Doe, Canon Law in the Anglican Communion (Oxford, 1998) 84.

${ }^{106}$ See eg Canada, Can. XIX; see also The Episcopal Church USA, Cans. IV.10, followed generally in Chile, Cans. B.7b; Brazil, Cans. IV.5,6; Mexico, Cans. IV.43-44.

${ }^{107}$ Southern Africa, Can. 19: "If any person in Holy Orders shall without consent from the Bishop abandon the exercise of his ordained ministry, or shall forsake the Communion of the Church, he shall not be allowed to resume the exercise of any Ministerial Office in this Church, until he shall have given to the proper authority evidence of the sincerity of his repentance for the fault which he has committed".

${ }_{108}$ M. Porter, "Bishop of the Murray faces long list of charges", Church Times, 12 March 2010.

109 That is, under ACAC, III.

${ }^{110}$ Church property is held on trust for the purposes of worship: PCLCCAC, Principle 80; in the Church of England, for example, the parish church is vested in the incumbent (and responsibility for its maintenance in a Parochial Church Council): see M. Hill, Ecclesiastical Law ( $3^{\text {nd }}$ edn., Oxford, 2001) 3.74; in the Church in Wales, ownership vests in provincial trustees, the Representative Body: see N. Doe, The Law of the Church in Wales (Cardiff, 2002) 302, 318ff; for other Anglican churches, see N. Doe, Canon Law in the Anglican Communion (Oxford, 1998) 308ff.

111 The civil law would of course be relevant here: see for example the recent case of Bentley $v$ Anglican Synod of the Diocese of New Westminster, heard in the Supreme Court of British Columbia, in which four parishes sought to leave the diocese with parish property: (2009) BCSC 1608. In the USA, judicial decisions in litigation concerning parishes seeking to secede from dioceses of The Episcopal Church USA have gone either way, depending on the precise terms of the trust instruments and State laws involved: for a brief overview of recent events, see eg G. Conger, "Legal battle looms as US church secedes", The Church of England Newspaper, 1 April 2010, 7.

${ }^{112}$ However, see below for liturgical ecumenism.

${ }^{113}$ PCLCCAC, Principle 56.1; see generally, N. Doe, Canon Law in the Anglican Communion (Oxford, 1998) $223 \mathrm{ff}$. 
body), and such texts must be neither contrary to nor indicative of a departure from the doctrine of a church in any essential manner; moreover, a bishop has limited authority to authorise new forms of service, for example for experimental use or for services for which no provision already exists in the authorised services. ${ }^{114}$ Anglican laws also provide for the dissolution of parishes and the sale of church buildings. ${ }^{115}$

Finally, there is the issue of copyright. This links property and liturgy. Once more, the Apostolic Constitution provides that an ordinariate may celebrate prescribed rites according to those liturgical books proper to the Anglican tradition "which have been approved by the Holy See". ${ }^{116}$ Let us assume that a group of Anglicans has left their church (and its buildings), and has entered an ordinariate. The ordinariate seeks to use the Book of Common Prayer 1662 in their services (let us say in a Roman Catholic church building). ${ }^{117}$ In England, for example, the Book of Common Prayer 1662 is not protected by statutory copyright, ${ }^{118}$ but it is protected by Crown Privilege: rights in the Book of Common Prayer 1662 are vested in the Crown and administered by the Crown's patentee, Cambridge University Press. ${ }^{119}$ It is not clear (without looking at the grant made by the Crown to Cambridge University Press or any other patentee), ${ }^{120}$ whether Crown Privilege extends to prevent reprinting the entire Book of Common Prayer or to reproducing substantial parts (the statutory copyright test for infringement); Copyright Guidance issued by the Church of England suggests the latter in that extracts of greater than 500 words require permission from the patentee Cambridge University Press. ${ }^{121}$ In short, if an ordinariate were to draft, and the Holy See to approve, a liturgical text containing extracts from the Book of Common Prayer, then as far as the Church of England were concerned, it would be prudent to obtain permission from Cambridge University Press. ${ }^{122}$ If other Church of England liturgical

\footnotetext{
114 PCLCCAC, Principle 55 (especially 55.4-9); see also 55.10: "No minister in a parish or other local unit may formulate or use a form of service for which no provision exists in authorised service books without lawful authority." This authority would probably not extend to services approved by Rome. ${ }^{115}$ PCLCCAC, Principle 21.2 (dissolution of parishes); Principle 80 (sale, etc).

${ }^{116}$ ACAC, III.

${ }^{117}$ PCLCCAC, 55.1: "The Book of Common Prayer 1662 is the normative standard for liturgy".

${ }^{118}$ Copyright Designs and Patents Act 1988; hereafter CPDA. I am very grateful to the Revd Simon Stokes for help with this paragraph. See generally S. Stokes, "Intellectual Property and the Church", LLM in Canon Law, Dissertation 1996, Cardiff, University of Wales.

119 Crown Privilege subsists independently from the CDPA - see s. 171(1)(b) CDPA; see Stokes (1996) for the background, history and the rationale for this. There is very little modern law on this area - the only recent case was the New English Bible case where the Crown Patentee The Queen's Printer Eyre and Spottiswoode were held to only have rights to the Authorised Version and not the New English Bible: see Universities of Oxford and Cambridge v Eyre \& Spottiswoode Ltd [1964] $1 \mathrm{Ch}$ 736 at 748 for a discussion of the right.

${ }^{120}$ Printing was historically controlled by the Crown which is where the practice as regards the $\mathrm{BCP}$ and AV originated. The privilege/words used in the grant of the patent for the AV (and hence BCP) were discussed in the NEB case.

${ }^{121}$ A Brief Guide to Liturgical Copyright, Archbishops' Council ( $3^{\text {rd }}$ edn., Church House Publishing, London 2000) p. 13: “Applications for permission for single use are not required for extracts of up to 500 words. Permission for other uses must be obtained" from Cambridge University Press.

${ }^{122}$ In order to be sure not to infringe, a request would be made to the copyright owner/crown patentee to grant a licence to cover the acts that would otherwise infringe; this is a voluntary licence (ie not statutory) - simply a matter of contract law - and a royalty might be requested. A licence may be refused in which case if publication/infringement goes ahead then the owner could seek an injunction as well as damages. The Copyright Guidance of the Church of England (see n. 121 above) indicates the current approach of the owners to granting licences. It can also be debated whether the privilege applies to electronic rights - clearly not contemplated by the Crown in the 17th century.
} 
texts were to be similarly used in an ordinariate, such as the Prayer Book as Proposed in 1928 , copyright permissions would similarly have to be obtained. ${ }^{123}$

\section{Anglican Laws which might facilitate the life of an Ordinariate:}

Former Anglicans, who have been admitted as Catholics to an ordinariate, may continue under Anglican laws to enjoy a connection with the Anglican churches which they have left. Various legal mechanisms enable this. First, in many Anglican churches ordinariate members will continue to enjoy the right to attend worship - this is certainly the position in the established Church of England: the right of all people resident in a parish, members of the church or not, to attend public worship at the parish church has been one recognised at common law; they will also continue to enjoy the right to marriage and burial at the parish church. ${ }^{124}$ They may also enjoy pastoral care: it is a fundamental principle common to churches of the Anglican Communion that ministers offer their pastoral ministry, with respect and compassion, and without unlawful discrimination, not only to members of the congregation but to all people as witness to the example of Jesus the Good Shepherd. ${ }^{125}$

Secondly, from an Anglican perspective, it may be lawful for prescribed authorities within a church to permit the administration of public worship in accordance with the rites of an ecumenical partner, subject to the satisfaction of conditions and to the extent permitted by the discipline of the partner church. This may be done on an occasional basis (for instance, where clergy of an ordinariate may be authorised to participate in an Anglican service). ${ }^{126}$ Or it may be done on a more permanent basis, typically in the form of a local ecumenical project. ${ }^{127}$ In the Church in Wales, for example, a diocesan bishop may authorise (by written declaration) the establishment of a local ecumenical project in a parish within the diocese; no such project can be established without the consent of the Bench of Bishops of the Church in Wales, the Diocesan Conference, and the relevant Parochial Church Council and incumbent of the parish concerned. Under such a project, a duly accredited minister, of another church, ${ }^{128}$ may officiate (according to rites other than those of the Church in Wales) at a service of holy communion, baptism, morning or evening prayer, and burial of the dead, with the written authorisation of the Anglican diocesan bishop; numerous other

\footnotetext{
${ }^{123}$ See A Brief Guide to Liturgical Copyright (2000) p. 13. The copyright of the Alternative Service Book (1980), discontinued in 2000, which vested in the Central Board of Finance, would qualify for copyright under CDPA like any other literary work and usual publishing practice would apply to getting permission: see A Brief Guide to Liturgical Copyright: the Archbishops' Council acquired title to it. The Book of Common Prayer 1984 of the Church in Wales vests in Church in Wales Publications; material in this was reproduced from the Book of Common Prayer 1662 with permission on the basis that the BCP 1662 is "Crown copyright".

${ }^{124}$ N. Doe, The Legal Framework of the Church of England (Oxford, 1996) 358 (right to worship: see Cole v Police Constable 443A [1937] 1 KB 316); for marriage and burial, see ibid., Chs. 13 and 14. ${ }^{125}$ PCLCCAC, Principle 44.1.

${ }^{126}$ See eg Church of England, Can. B43: ministers in good standing in their own church may be invited to perform certain duties within Church of England services if they are authorised to perform similar functions in their own church; the incumbent invites, and the bishop and/or parochial church council approves; joint worship might also occur as might worship in accordance with the forms of service of the other church.

${ }^{127}$ PCLCCAC, Principle 97.3: “A parish may enter a local ecumenical project to provide for shared ministerial, liturgical or sacramental communion or other form of reciprocity agreed by the participant churches, in the manner and to the extent authorised by law".

${ }^{128}$ Ie: a church other than the Church in Wales or a church in communion with the Church in Wales.
} 
conditions have to be satisfied. There are also provisions dealing with terminations of such projects. ${ }^{129}$ It is possible, from an Anglican perspective, that in such churches local ecumenical projects may be entered with Catholic ordinariates.

Thirdly, some Anglican churches participate in church sharing agreements, and it may be worthwhile exploring the possibility of sharing agreements between Anglicans and Catholic ordinariates. This is the position in England, where civil law expressly facilitates the sharing of church buildings by the Church of England and the Roman Catholic Church. A church building vested in the Church of England must continue in Church of England ownership. To enter a sharing agreement, for the Church of England the diocesan board of finance, the incumbent and the parochial church council must each be a party to the agreement; for the Roman Catholic Church, the party shall be that as approved by the diocesan bishop. Before a sharing agreement can be made, the consent of the Church of England bishop and the pastoral committee of the diocese must be obtained. The agreement (a statutory covenant) may be amended with the agreement of the parties and the statutory consents. The purposes of a sharing agreement are protected by way of trusts and the agreement must provide for financial and management issues. It must also provide for determining the extent to which the building is to be available for worship in accordance with the forms of service and practice of the sharing churches and it may provide for the holding of joint services, as well as rites for the solemnisation of marriage. The faculty jurisdiction of the Church of England continues to apply to all consecrated buildings which are the subject of a sharing agreement (but it does not extend to movables required for the worship of any sharing church other than the Church of England). ${ }^{130}$ It is possible that a sharing agreement could be made with an ordinariate.

Finally, it may be possible, in the fullness of time, to explore the possibility of some connection between a Catholic ordinariate of former Anglicans and the Anglican Communion itself. At international level, as we have seen the Anglican Communion has no formal body of law applicable globally to its forty-four churches in communion with the See of Canterbury; each church is autonomous with its own legal system. The Communion is held together by "bonds of affection": shared loyalty to scripture, creeds, baptism, eucharist, historic episcopate, and its institutional instruments of communion - Archbishop of Canterbury, Primates Meeting, Lambeth Conference, and Anglican Consultative Council, but these cannot make decisions binding on churches. ${ }^{131}$ However, the Communion is currently debating adoption by each church of an Anglican Communion Covenant on faith, mission and ecclesial relationships; this is currently before the churches for adoption. ${ }^{132}$ Signing the covenant does not represent submission to any external Anglican jurisdiction. ${ }^{133}$ The

\footnotetext{
${ }^{129}$ Church in Wales, Can. 26-9-1991; see also Church of England, Can. B44 and Church of Ireland, Const. IX.11.

${ }^{130}$ Sharing of Church Buildings Act 1969; this also applies to the Church in Wales. The position of the Church of England under a sharing agreement is also governed by Canon B44 (see above).

131 See generally N. Doe, Canon Law in the Anglican Communion (Oxford, 1998).

132 The idea was proposed in the Lambeth Commission on Communion, The Windsor Report

(London, 2004) paras. 113-120; see generally, N. Doe, An Anglican Covenant: Theological and Legal Considerations for a Global Debate (London, 2008). For the idea that "“covenant' does not introduce an alien notion into Anglicanism", see N.T. Wright, "A scripture-formed Communion? Possibilities and prospects after Lambeth, ACC and General Convention", 7 Journal of Anglican Studies (2009) 163 at 179 .

${ }^{133}$ Anglican Communion Covenant, 4.1.3.
} 
covenant provides that: "The Instruments of Communion may invite other Churches to adopt the Covenant using the same procedures as set out by the Anglican Consultative Council for the amendment of its schedule of membership"; however, "[a]doption of this Covenant does not confer any right or recognition by, or membership of, the Instruments of Communion, which shall be decided by those Instruments themselves". ${ }^{134}$ It would be ironic indeed if such a facility, or at least the concept underlying it, were to prove a basis upon which further ecumenical dialogue were possible between the Anglican Communion and the Catholic Church.

\section{Conclusions}

The Apostolic Constitution, Anglicanorum Coetibus, has stimulated a wide range of responses in worldwide Anglicanism, from hostility to what is perceived as an action inconsistent with the ecumenical spirit, to statements of intent to petition Rome for admission to its personal ordinariates. The ordinariate concept is known, but as a rarity, to Anglican canon law. Above all, an ordinariate will enable former Anglicans to become Catholic and to enter full communion with Rome, with all that entails in terms of integration within a new canonical order. It will also enable ordinariate members to continue aspects of their liturgical, pastoral, spiritual and synodal traditions. It is surprising though, given that many of the experiences which Anglicans will bring to the ordinariates, that the Apostolic Constitution fails to acknowledge the canonical tradition of Anglicanism. However, for those Anglicans who wish to be obstructive, there are many facilities in Anglican canon law to respond negatively to this development: removal of those who join an ordinatiate from ecclesial status and membership in their former churches will not be problematic, but the (theoretical) possibility of disciplinary action against them (for abandonment of their membership and ministry) could be devastating for ecumenical advancement. On the positive side, there are equally several mechanisms in Anglican canon law, to enable a continuing connectedness of ordinariate members to Anglican life and worship, subject of course to the discipline of their new (Roman Catholic) Church. Church sharing agreements, at least in a small number of Anglican churches, are possible ways of achieving some form of connectedness with Anglicanism.

${ }^{134}$ Anglican Communion Covenant, 4.1.5. 


\section{QUESTIONS FOR DISCUSSION:}

1. To what extent does the Latin Church have a duty to take into account the effect its policies might have on the well-being of Anglicanism?

2. Is the state of Anglicanism any business of the Latin Church?

3. Did Rome anticipate the range of responses from Anglicans worldwide?

4. To what degree was the canonical tradition in Anglicanism considered during the process leading up to the promulgation of the Apostolic Constitution?

5. To what extent did Rome take into account the juridical obstacles which Anglicans who oppose admission to an ordinariate might employ in response to the departure of those Anglicans seeking to enter an ordinariate?

6. What are the consequences under the Latin Code for those of the Catholic faithful who seek to leave the church?

7. To what extent does Latin canon law facilitate the sharing of church buildings? 